Article

\title{
Israelijew Jewisraeli: Yoram Kaniuk's Adam Resurrected and the Problem of the Human
}

\author{
Netta van Vliet \\ Cultural and Political Anthropology, College of the Atlantic, Bar Harbor, ME 04609, USA; nvanvliet@coa.edu
}

Received: 16 February 2020; Accepted: 10 March 2020; Published: 28 March 2020

check for updates

\begin{abstract}
This article considers the political and philosophical genealogies of the category "Israeli Jew" in terms of Israeli novelist Yoram Kaniuk's Adam Resurrected, which I situate within the wider context of contemporary Israel. Israel is defined by some as a colonial and occupying state and by others as a liberal democracy founded on narratives of modern nationalism, but also on the Abrahamic narrative of 2000 years of Jewish exile. The category "Israeli Jew" thus brings together the figure of the diasporic Jew as not fully sovereign with Zionism's figure of the "New Jew," based on European modernity's ideal of a sovereign, autonomous, citizen subject. I show how, by bringing these figures together, rather than replacing one with the other, the category "Israeli Jew" brings together the specificity of the different genealogies that these terms carry. In this regard, I argue, Israel can be understood as an instantiation of the historical legacy of the philosophical binary between the Athenian and the Hebraic, which, as Miriam Leonard, Jacques Derrida, and others have pointed out, informs the long durée of Western political philosophy.
\end{abstract}

Keywords: Israel; Zionism; difference; Derrida; literature; deconstruction

\section{Introduction}

German Jewish philosopher Leo Strauss, in the preface to the English translation of his Spinoza's Critique of Religion, wrote:

The establishment of the state of Israel is the most profound modification of the Galut [the Diaspora, or Exile] ... , but it is not the end of the Galut: in the religious sense, and perhaps not only in the religious sense, the state of Israel is a part of the Galut. Finite, relative problems can be solved; infinite, absolute problems cannot be solved ... it looks as if the Jewish people were the chosen people in the sense, at least, that the Jewish problem is the most manifest symbol of the human problem as a social or political problem. (Strauss 1965, p. 6)

While Strauss and his contemporaries remarked on Zionism and Israel in terms of the challenges that Jewish difference posed for the political frameworks of European liberalism, present-day debates about Israel rarely address the question of Jewish difference. References to the political histories out of which Israel emerged draw on the principles of European Enlightenment, rather than calling them into question. Whether a pariah in the world's "family of nations" or an exceptional model to be emulated, Israel is debated, criticized, and defended within the terms of European liberalism. Critics argue that Israel should fall in line with the ideals of European liberal democracy; defenders insist that Israel already does (Pappe 2014; Shafir and Peled 2002; Yakobson and Rubinstein 2010; Yiftachel 2006). In a significant departure from the two lines of analysis that dominate the literature about Israel, this article argues neither for an understanding of Israel as the latest form of settler-colonialism, nor for an understanding of Israel as a European liberal democracy that is the latest stage of Jewish presence in the region. Rather, it shows how an analysis of the conjunction "Israeli Jew" and its political and 
material effects challenge European modernity's binaries of East and West, Jew and non-Jew, guest and host, madness and reason, and feminine and masculine on which humanism's concept of the human is founded. In so doing, an analysis of the category "Israeli Jew" reveals how what Strauss termed a human problem can be understood instead as a problem of how the human itself has been defined in the context of European modernity.

This article considers the political and philosophical genealogies of the category "Israeli Jew" in terms of Israeli novelist Yoram Kaniuk's Adam Resurrected, which I situate within the wider context of contemporary Israel. Israel is defined as a liberal democracy founded on the narrative of modern nationalism, but also on the messianic Abrahamic narrative of 2000 years of Jewish exile. The category "Israeli Jew" thus brings together the figure of the diasporic Jew as not fully sovereign, with Zionism's figure of the "New Jew" based on European modernity's ideal of a sovereign, autonomous, citizen subject. By bringing them together, rather than replacing one with the other, the category "Israeli Jew" brings together the specificity of the different genealogies that these terms carry. In this regard, Israel can be understood as an instantiation of the historical legacy of the philosophical binary between the Athenian and the Hebraic, which, as Leonard (2012), Derrida (1999), and others have pointed out, informs the long durée of Western political philosophy.

If the figure of the Israeli Jew makes explicit the co-existence of European and non-European-or Greek and Jew-within the production of the postcolonial masculine subject, then the reproduction of a polity defined in the name of this figure brings this genealogical line of origin as it is configured between two differently marked men into an encounter with the difference of woman. By posing a question about how to understand sexual difference, a consideration of Israeli Jewish sovereignty not only reanimates the "Jewish Question" but also-beyond Israel—calls into question notions of the liberal, universal sovereign subject. Such an analysis, I suggest, has profound implications for how we understand the consequences of European humanism's concept of the human, as well as the politics through which Europe and its colonial legacies took shape.

There has been increasing attention to the fact that there are aspects of Israeli society that do not fall neatly into binaries such as religious and secular (Boyarin 1996; Engelberg 2015), Arab and Jew (Shohat 2017), colonizer and colonized (Kalmar and Penslar 2005; Penslar 1991), and Hebrew and Arabic (Levy 2014). I build on these insights by suggesting that these are not anomalies, coincidental, or exceptions to Israel and its political framework as a Jewish liberal democracy. Rather, I argue, they are at the core of what defines Zionism and Israeli society. Arab Jews or Mizrahim, the overlap between "secular" and religious," and the "soldiers who shoot and cry," along with a multitude of other compositions of what are otherwise understood as binary oppositions, contradictions, or hypocrisy, are all products of the same histories that bring "Jewish singularity" and "European universalism" into the single figure of the Israeli Jew (see also Bartal 2010).

There is a growing clamor, both in formal academic publications as well as in the halls and panels of academic conferences and online spaces, for Israel to be boycotted or otherwise sanctioned for violating the principles of liberal democracy. For example, Gianni Vattimo and Michael Marder, editors of the recent Deconstructing Zionism, describe Israel as "a state that, to this day, re-founds and legitimizes itself based on a mix of millennia-old theodicy and a frozen mold of nineteenth century European-type nationalism, which has not survived in this form anywhere in Europe" (Vattimo and Marder 2014, p. $\mathrm{xv}$ ), as if European countries have advanced beyond the problems of how to address difference within the context of liberal democracy out of which Israel itself emerged, and that Israel needs to catch up to its European counterparts. ${ }^{1}$ Similarly, calls for boycotts or divestment through analogies with South African apartheid (Butler 2012; Palumbo-Liu 2015) and those who defend Israel against such calls (Nelson and Brahm 2014) elide the differences between Israel's political framework and South Africa's apartheid regime. Whereas in apartheid South Africa, it would have been impossible to have a

1 The framework of their edited volume suggests a significant misreading of deconstruction (see van Vliet 2016). 
black judge sentencing a white anti-apartheid activist to community service for actions in solidarity with black anti-apartheid activists, in Israel, it is possible to have a Palestinian judge sentencing a Jewish-Israeli activist for acts of anti-occupation solidarity with Palestinians. My point here is not that such differences signify that there is justice for or equal treatment of Jews and non-Jews within Israeli society, juridically or otherwise. There is not. Nor is it to suggest a hierarchy of suffering or of oppression. Rather, my point is that apparent contradictions in Israel reveal not a failure to abide by liberal democratic principles but, rather, the failure of liberal democracy to address the question of difference. The rest of this essay is dedicated to explaining what I mean in making this claim.

\section{Israeli Jew: Israel and the Jewish Question Revisited}

The "Jewish Question" was defined in turn-of-the-century Europe as a question about the degree and manner to which Jewish difference was or was not compatible with the ideals of European modernity (Librett 2014), as well as with political projects that took shape with and against its geopolitical contexts (Bauer [1843] 2000; Marx [1844] 2012; Peled 1992). What defined "Jewish difference" was part of this question. Questions about whether the Jew is defined by anti-Semitism; whether the Jew is a cultural, religious, ethnic, racial, or biological identity; and whether the Jew can assimilate or not were debated by Jews and non-Jews, within and outside the Zionist movement, within and outside Haskala, and in fin-de-siecle European scientific and medical discourse (Feiner 2002; Boyarin 1997; Gilman 1991; Idelson-Shein 2014). These questions overlapped with broader discussions about race, degeneration, sexuality, aesthetics, morality, economy, and Enlightenment ideals of freedom, sovereignty, and equality. As Miriam Leonard writes, "Throughout the nineteenth century and across the whole of Europe, the issue of the treatment of the Jews was inextricably bound up, on the one hand, with the project of social and political reform, and, on the other, with the attempts to define the integrity of the nation-state" (Leonard 2012, p. 7). These attempts culminated in the expulsion and mass killing of Europe's Jewish populations and then in the efforts of Europe and its allies to reassemble in the aftermath of the war.

Zionism, in the views of its most prominent leaders, was a response to the sense that Jewish difference was inassimilable in the context of European liberal democracies. As Conforti (2006) has pointed out, this did not mean that Zionists were unified or otherwise in agreement, contrary to post-Zionist polemics about Zionist history. How Jewish difference was understood in relation to European Enlightenment's universalist ideals informed the views not only of those at the heart of the Zionist movement, but also of thinkers such as Martin Buber, Franz Rosenzweig, Gershom Scholem, Emmanuel Levinas, Walter Benjamin, Hermann Cohen, Hannah Arendt, Leo Strauss, and Sigmund Freud. Their pronouncements and sometimes painful ambivalences regarding Zionism and Israel were part of wider philosophical and political debates of twentieth-century Europe, which at the time of Israel's establishment, was reeling from two world wars, the breakup of Empires, anti-colonial struggles in its colonies, and hopes and disillusionments born, in part, of the French Revolution more than a century earlier.

The establishment of the state of Israel in 1948 thus happened in the context of international tensions that were part of the political disorder of Europe and its colonies in the aftermath of WWII. When the war ended on 8 May 1945, Europe was faced with multiple challenges: how to deal with war refugees and displaced populations and how to address the questions of responsibility for the war's atrocities. As the British in Palestine sought to limit Jewish immigration, tension between the British and the Jews in Palestine intensified (Smith 2007). What came to constitute "Israeli" was thus specific not only to the situations of Jews in different national contexts but was also specific to transnational contexts shaped by Europe's relations to its colonies and to its internal others and by the Cold War. Jews thus arrived to Palestine and then Israel for very different reasons, with different cultural and political backgrounds and investments. In this context, Israel was explicitly marked as a Jewish country and refuge for Jews and as a liberal democracy and member of the world's "family of nations." However, precisely because of the diverse histories of Jewish difference and the Jew's position in relation to the 
category of modern secular citizenship, the establishment of Israel as a Jewish liberal democracy has continued to pose the question of what defines Jewish difference.

Theodor Herzl famously referred to Zionism as a dream about the creation of a Jewish homeland, both in his fictional depiction of Zionist settlement in Old New Land and in his call to action in The Jewish State. ${ }^{2}$ The establishment of the State of Israel is commonly understood within Zionism as the realization of that dream. This dream of another place for the Jew also carried with it a dream of another kind of Jew. This Jew would be a new Jew, or what leading Zionist Max Nordau called "the new muscle Jew" with a place of their own rather than wandering from place to place, with a new language taken from the old-a language of their own. The "New Jew" would be a Jew with a new character; the New Jew would shed the characteristics of the diasporic Jew and be strong, in touch with the land and physical labor, tanned by the sun rather than pale from staying indoors studying the Torah, carefree and independent rather than anxious and melancholic (Abramson 2011; Mosse 1992; Nordau 1897). ${ }^{3}$ As (Abramson 2011) has importantly pointed out, Zionism's "New Jew" went through different incarnations and was shaped by diverse influences in addition to Nordau's famous "muscle Jew," including Martin Buber's "Renaissance" Jew, Michah Yosef Berdyczewski's Nietzschean "New Man," and Herzl's "authentic Jew." As Sander Gilman (1993a, 1993b) and others have pointed out (Boyarin and Boyarin 1997; Pellegrini 1997; Rolnik 2013; Slavet 2009; Yerushalmi 1993), Zionism can also be understood in tandem with psychoanalysis as a different but overlapping response to the pathologization of what was commonly understood as "degeneration" and nervous disorders of melancholia and hysteria within the context of European modernity. Indeed, Zionism's emergence as a response to anti-Semitic exclusion from European modernity's universalist ideals took shape in overlapping political and intellectual conditions with psychoanalysis. ${ }^{4}$ In this sense then, in ways both similar to and different from psychoanalysis, Zionism sought to remake Jewish difference in the terms of self-possession, sovereignty, and autonomy. However, it did so precisely in the name of defending the Jew as not self-possessed or sovereign. The figure of the (new) Israeli Jew is thus haunted and undone by the diverse histories of the diasporic Jew.

The category "Israel Jew" therefore also draws attention to the implications of how Jewish difference is defined for the definition of the modern, liberal secular citizen subject of European modernity. By simultaneously declaring itself to be Jewish and not only a liberal democracy, Israel continually poses challenges to the assumptions of the possibility of the metalanguage presumed by the law and grounded in European modernity's political frameworks of a liberal humanism, or in Dipesh Chakrabarty's terms, "the concept of the universal and abstract human who bears" the Enlightenment themes of juridical freedom (Chakrabarty 2000, p. 50). To ask how the proper name "Israel" is haunted by the proper name "Jew," or how the category of the universal and abstract citizen is haunted by the Jew, requires placing the narratives of Jewish exile and return in the context of WWII and its aftermath and in the context of European nation-state formation. ${ }^{5}$ I now turn to consider what might be learned from an analysis of the category "Israeli Jew" in these terms, through a reading of Israeli novelist Yoram Kaniuk's Adam Resurrected (Kaniuk [1969] 1971).

\footnotetext{
See (Herzl [1902] 2009) and (Herzl [1896] 2018).

See Almog (2000) for a vivid fictional account of the ideal of the Sabra.

For discussions of the historical overlap between Freud and Herzl, see Loewenberg and Stone (1970); Avner (1996).

"Jew" in this sense suggests that a proper name can never be autonomous or owned by only one (in the sense of being singular plural, see (Nancy [1996] 2000), which then presents the question of what kind of "ownership" this would be. In his rereading of the story of Babel, Derrida suggests that the text of the story can be understood as conveying a double injunction from God: "translate me, translate my name," and "don't translate me, don't translate my name, you won't be able to" (Derrida 1985, p. 77). Derrida suggests that such a double command, or in his word, "desire," is at work in every proper name.
} 


\section{Israelijew Jewisraeli: Greekjew Jewgreek and Yoram Kaniuk's Adam Resurrected}

Kaniuk's novel Adam Resurrected, first published in Hebrew in 1969 (with the title Adam Ben Kelev), tells the story of Adam Stein, a Holocaust survivor who was a clown and violinist by profession, who survives the concentration camps by clowning under the gaze of his Nazi commanders in front of the lines of camp inmates as they walk to their deaths in the gas chambers and by living as a dog with the four legged canine Rex in the apartment of his Nazi commander Herr Klein and his wife. ${ }^{6}$ After the war, Stein goes to Israel, where, after he attempts to kill his German Jewish landlady with whom he is involved in an amorous relation, he is taken to an insane asylum for the rehabilitation of Holocaust survivors.

Throughout the book, Adam is visited by his twin brother, Herbert, who appears as a ghostly presence on Adam's windowsill in his room in the asylum. When Herbert is first introduced in the book, it is soon after Adam is brought back to the asylum after trying to strangle his German landlady in Tel Aviv. Soon after Adam arrives back in the asylum, he is visited by his twin,

who was a philosophy student in Heidelberg and studies under Professor Maritain and under old man Ludwig, the author of The Lucky columns, somebody who will never acknowledge the bitter truth that Adam Stein, his twin, was a circus clown who became the lowest of the low, namely, 'the Jew who made Klein laugh,' the Jew who performed there, twisted his nose and prestidigitated, and all this in front of his proud wife, Gretchen. (Kaniuk [1969] 1971, p. 59)

\section{Adam says,}

'But Herbert, my brother, we remained alive on account of my clowning and not on account of your being a famous Hegelian ... ' Adam is tense, his body one taut bow; soon he will hear the keys in Shapiro's hands clank and the door slam, soon the swish of the lock and the background music in the hallway will vanish and just the two of them will be left, he and Herbert, and then he can die. Meanwhile Herbert is still on the windowsill, as the white of the Dead Sea flickers in the distance and signals crooked images with its rays.

Herbert then replies, "Adam Stein, you amaze me. You're miserable, very miserable. And to think we two are caught in one body. It's weird, really weird. And sad. Above all, sad."

Adam clenches his fist. How ridiculous he is, this perpetual student sitting on the windowsill. 'Get down from the window, you beast of prey. You're driving me crazy.'

'Me?' Herbert bursts into such laughter that it shakes the mountains of Judah, the desert, the ancient Dead Sea, the salt flats, Lot's wife, the Essenes, Elijah. 'That makes two of us. If you're crazy, so am I.' (Ibid.)

The figure of Adam Stein is haunted by his Jewishness in the form of his twin brother Herbert, the secular, modern philosopher German Jew, and in the form of his former self as a Jew who survived the Holocaust by living as a dog. As an Israeli Jew, he is caught between the modern citizen subject modeled on the figure of the Greek and the Jewish Abrahamic subject, based on the narrative of 2000

6 My discussion here focuses on the English translation of Kaniuk's novel. The Hebrew title, Adam Ben Kelev, translated literally, is "Adam Son of a Dog." In this essay, I do not focus on the Israeli political events of the 1960s that shaped the context within which Kaniuk was writing. For considerations of Kaniuk's work in terms of the 1960s Israeli political contexts and literary canons of which it is part see Hess (2016); Shaked and Peleg (1996).

It should also be noted that there is a 2008 film based on the novel, with the same title, "Adam Resurrected," directed by Paul Schrader, with Jeff Goldblum cast as Adam. While the film version is able to convey the theatricality and absurdity of many aspects of the novel in ways that perhaps surpass the novel itself, the film is unable to present the ambivalence of how dog/human boundaries are confounded in the same way as the book, as in the film, the viewer sees either a dog or a human acting like a dog. More significantly in terms of my discussion of the novel here, the film does not elaborate on Adam's subjectivity through his relation to his twin brother Herbert; the dialogues with him in the novel are absent in the film. 
years of exile and return. It is precisely because the Jew could not survive in Europe in the form of his brother Herbert that Jew is redefined as both Jew and Israeli; he is both the Jew of the Abrahamic narrative of exile and return and the citizen based on the Greek narrative of metaphysics. In this sense, Stein brings together the different genealogies attached to these narratives and their binary oppositions of reason and madness, inside and outside, and secular and religious. He can thus be understood to contain a relation between two different men, Jew and "non-Jew," or Jew and Greek, within the genealogy of European modernity.

As Leonard (2012) has pointed out, the concept of the Jew as outside of the framework of the modern nation-state was prominent not only in existentialist and postwar thought, but also was an explicit element of European Enlightenment thinking and particularly of German philosophy. Hegel, she writes,

reveals how the Jews do not actually own their land, they have it merely as a loan from their God. As such, they have no concept of family property. 'The Greek process founds rights and politics, constitutes family subjects as citizens. The Jewish process, on the contrary, scoffs at rights and politics.' The Jews are stuck in the same double bind that has marred their existence since Noah. They are incapable of being citizens because they are incapable of being a family, incapable of being a family because they lack the political rights of the citizen. In the end, for Hegel, the Jews cannot be citizens because they are not Greeks. (Ibid., p. 91)

By tracing what she calls "the persistent figural 'work' done by the Greek/Jew couplet in giving form to a range of Enlightenment and post-Enlightenment philosophical, social, and political concerns" (Ibid., p.12), Leonard offers an account of how the figure of the Jew has shaped the history of ideas through which European modernity and post-Enlightenment political frameworks have come into being. In so doing, she provides an analysis of the historical philosophical foundations through which an opposition between Athens and Jerusalem has been a powerful signifier in European thought and shows how "the Greek/Jew opposition is an exemplary case, if ever one was needed, of how symbolic structures come to have consequences in the 'real' world" (Ibid.). In the literary imagination, this opposition appears most famously in the work of James Joyce in Ulysses. Joyce himself was informed, as Davison (1998) has traced, by different engagements with the notion of the Hellenic Hebraic relation in Culture and Anarchy (Arnold [1869] 2009) and in Nietzsche's philosophical writings.

This internal difference between Greek and Jew within a single subject is produced in the context of Israel through the establishment of a polity in the name of this figure. The category "Israeli Jew," by bringing together the philosophical coupling of Greek and Jew within a single figure, places the figure of the Jew simultaneously in the position of host and of guest. This relation in which the Jew is both guest and host to another within a single subject, can also be understood in terms of the position of Jew as guest on the scale of the nation-state, and in relation to God, in the narrative of modern nationalism and in the messianic narrative of exile and return.

Historically, the figure of the Jew has been understood as that of guest both in terms of genealogies of modern nationalism and in terms of Biblical narratives. In terms of the former, the figure of the Jew is situated as guest by definition, as thinkers as different as Jean-Paul Sartre, Theodor Herzl, Sigmund Freud, Hannah Arendt, Max Nordau, and Jacques Derrida have all suggested, albeit in significantly different ways and with different implications. What makes a Jew a Jew in relation to European nationalisms, they differently suggest, is tied to a genealogical narrative that defines the figure of the Jew as always in excess of and before and beyond the nation-state, originating from elsewhere and destined for elsewhere. Thus, even the most assimilated Jew, if there is any remainder of Jew left, remains defined as guest in relation to the nation-state. In terms of the Biblical narrative, as Lévinas (1994) and Derrida (1999) have both differently emphasized, the Old Testament introduces the Jew as a guest of God, both in relation to language and land; the Jewish people are guests of the Hebrew language and guests in the land promised to them by God. The narrative of more than 2000 years of exile thus situates the Jew as guest both in terms of the Biblical narrative of exile from an 
original homeland where they were guests of God and in terms of the Jew's relation to the modern nation-state form.

It is precisely because Israel is based on the model of European liberal democracy and simultaneously defines itself as Jewish in terms of the messianic narrative of exile and return that the conjunction Israeli-Jew can be understood as making explicit the Greek/Jew opposition, in which the Jew is simultaneously in the position of host and of guest vis-à-vis the nation-state. By bringing together the categories "Israeli" and "Jew," without subsuming one within the other, the establishment of Israel as a Jewish liberal democracy has positioned the figure of the Israeli Jew as simultaneously host and guest. When Jew becomes joined with Israeli through the establishment of a Jewish liberal democracy, Israel Jew thus becomes host, while remaining also guest, within a single subject position.

Adam Stein condenses Greek and Jew in a single subjectivity in a way that echoes the politics of contemporary Israeli Jewish national identifications and state policy. He represents the man of reason and of madness, the animality of Jewish difference and the non-Jewish human mastery of the animal, God and the (Jewish) man named by God, the German and the Jew, the Greek and the Jew, the universal and the particular, violence and pleasure, the Kantian philosopher (in the specter of his "twin brother") and the Jew ridiculed by and excluded from this philosophy, the citizen and the non-citizen, the masculine and the castrated, circumcised, and emasculated, but importantly, not the feminine.

\section{Israeli Jew, Host and Guest, Sexual Difference}

How are we to understand how the relation of the Jew and non-Jew, or the co-existence of Herbert and Adam "in a single body," within a single subject in relation to the figure of woman, through whom the collective people in the name of this single subject-Herbert Adam or Israeli Jew-is reproduced as a group? It is through an attention to this question of reproduction that Khanna (2014b) brings James Joyce's Ulysses and the Greekjew coupling it references to bear on a consideration of Kaniuk's novel. In her discussion of Zionism in terms of the concept and practice of asylum, she reads Adam Stein through the figure of Leopold Bloom in Joyce's Ulysses and the figurative relation between Greek and Jew in geographical terms, which she connects to a discussion of sexual difference.

Drawing on Miriam Leonard's consideration of the relation between Hebraism and Hellenism, Khanna situates Stein in terms of this relation, which "is set up from Roman times to the present between the Greek and the Jew from Tertullian to James Joyce: between Hellenism and Hebraism, Christianity and paganism, rationality and irrationality, secularism and religion" (Khanna 2014b, p. 137). She suggests that this coupling can be understood in terms of a geographical binary, which "points towards a quintessential difference, one could say: the sexual difference. The oft-quoted line from James Joyce's Ulysses highlights the blind spot to difference as encapsulated within sexual difference-'Women's reason: Jewgreek is Greekjew. Extremes meet'" (Ibid.). She goes on to suggest that while Miriam Leonard rightly understands this as referring to an idea of women's irrationality, it can also be understood as opening

to a form of a yet to be realized feminine difference that became so important for Derrida ... which plays indeed also with the sense of internal exile from a site of belonging ... we could understand this autobiographically as being a Jew in Oran, Algeria during the moment of the abrogation of French citizenship of Jews during the Vichy regime. (Ibid.)

Khanna defines this feminine difference here in terms of a geographical binary between Athens and Jerusalem, as a difference that is suppressed in a political framework based on belonging that does not acknowledge internal exile-those who are "exiles unto themselves, contained within a shared space" (Ibid.). In this sense, postcolonial difference is understood in terms of the internal exile produced by the erasure of a relation to origin through which feminist theory has defined sexual difference. As Elizabeth Grosz has put it, drawing on Luce Irigaray (1987), 
the containment of women within a dwelling that they did not build, nor was even built for them, can only amount to a homelessness within the very home itself: it becomes the space of duty, of endless and infinitely repeatable chores ... the space of the affirmation and replenishment of others at the expense and erasure of the self. (Grosz 1995, p. 122)

Considering Israel in terms of asylum and the internal exile of postcolonial difference is thus to follow through with Khanna's argument elsewhere that one must reconsider Irigaray's discussion of the speculum that brings the question of origin and womb back into Western philosophical discourse by bringing postcolonial difference to bear on the manner in which Western metaphysics erases a relation to origin (see Khanna 2003).

Khanna shows how the "passage between" that is erased in the Platonic metaphor of the cave is a passage not only between the terms "man" and "woman," but also between the image of the ideal of the universal man and the marked postcolonial man. She writes,

[Frantz] Fanon's example of the disappearing black who is perceived as invisible first by whites and then consequently, according to Fanon, by blacks, raises a number of important issues that relate to the status of the material and the manner in which it shares in the constitution of subjectivity ... In the eyes of others, subjectivity disappears. This is, of course, different from the threat to one's own subjectivity by the imago in the mirror, because it is suggestive of the mechanisms that constitute the mirror itself. It is not something transparent, or something through which assurance of existence can be guaranteed in a familiar 'mirror' pose... (Khanna 2003, pp. 181-82)

The mirror itself is here highlighted as not ever a universal, unmarked mechanism through which one's image is reflected. In other words, in a manner that elaborates on Irigaray's move to think about image making in terms of the concave dimensionality of a speculum rather than the flatness of a mirror, Khanna points out that the technology through which one's image is made is itself historically, economically, and biologically marked. When, "in the eyes of others, subjectivity disappears," it is through eyes that see a reinforcement of the ideal of the universal human, through which difference is objectified or made invisible. In other words, it is the non-place of the marked woman who forces a consideration of these two genealogical lines simultaneously. An analysis of the figure of the postcolonial woman thus raises the question of how the constitution of European modernity's concept of the human is defined in relation to the man marked as both inside and outside European modernity's universal human, i.e., the postcolonial or Jew. The "human problem" to which Leo Strauss refers in terms of "the Jewish problem" can thus be understood as a problem of how the human itself has been defined within European modernity. An analysis of the figure of the Israeli Jew points to how the constitution of the human leads to a question about the difference of woman in relation to the reproduction of the postcolonial.

Khanna calls attention to the fact that Kaniuk's novel does not, as she puts it, "adequately address the loss of the feminine that leads to the patrilineal parthenogenesis of dog-children" (2014b, p. 141). In the novel, Adam Stein's Israeli self that has survived from the ashes of the Holocaust can be understood as the offspring of the relation between his dog self and his Nazi commander Herr Klein. In the asylum in the Negev desert, Adam in turn "fathers" a dog-child when he "rehabilitates" a child inmate (who at first is more dog than child) from dog into child. It is, as Khanna suggests, through an attention to the specificity of the relation of hospitality between men that this loss of the feminine may be addressed. But to do so means to refrain from eliding or analogizing the internal exile of the postcolonial man and the internal exile of feminine difference. It is exactly through attending to their relation in terms of how they are distinct from one another that it is possible to address the question of what feminine difference is. This question then turns us to the question of how the human has been defined through an understanding of the difference of a people.

Bloom, and similarly but even more explicitly, Adam Stein, are understood as postcolonial men, which is to say that their internal exile is produced exactly by the condition of postcoloniality. In this 
reading, Stein is a reiteration of Leopold Bloom, who, Khanna points out, can be understood as "the quintessential wandering Jew of literary modernism" (Ibid., p. 137). It is then precisely the question of reproduction of the postcolonial polity, in this case Israel, which demands an attention to the difference between the internal exile of the postcolonial and the internal exile of the feminine. To conflate the internal exile of feminine difference with that of postcolonial difference is to leave unaddressed the relation-and importantly, the difference-between the relation of guest and host within individual subject formation, marked in terms of the difference of a people, and the relation of guest and host between peoples, marked in terms of the difference of sex within a people. We can therefore read the novel in terms of an analysis of the genealogy of the Israeli Jew that would suggest the feminine never was present and thus was not lost but, rather, served as a prosthetic support for the production of the human in terms of a difference among men.

In the novel, the feminine only exists in the form of animality, death, or violent eroticism. It is an act of erotic but potentially deadly violence against the German landlady Ruthie Edelson from whom Adam rents a room in Tel Aviv that lands him back in the Negev asylum; Ruth is also the name of his daughter who survived the war and came to Israel only to die in childbirth, and it is the name "Ruth" that, in the office of the asylum's director, Dr. Gross, is recalled under the gaze of a portrait of Sigmund Freud and that gets "stuck in his throat and wouldn't come out" (Kaniuk [1969] 1971, p. 23). Similarly, it is through overdetermined transferential relations between people haunted by the name of the dog through which Adam, at his daughter's grave without a gravestone in Israel, tries to understand what it means to be a Jew, a man, a father, a husband, a human, and a survivor. The relation between guest and host, marked as the difference of a people within the figure of the postcolonial man, thus confronts the question of the reproduction of the group in relation to the figure of woman.

There in the cemetery, at the site of his daughter's grave, his son-in-law's words "Now make her laugh. You're funny, aren't you?" (Ibid., p. 143), ordering him to make his dead daughter laugh, return Adam to the words of Herr Klein to him and to Klein's dog Rex with whom Adam shared a bowl and a master:

Adam stares at him. He can't understand, but the words ring a distant bell in his ears. Now/you/must/make/her/laugh ... Klein's command! Herr Stein, your life for your clowning ... Rex, don't bark, this man is your brother. You're a purebred and he's a mongrel. Who will win out, the pure Jew or the pure dog? The pure dog lost because the pure Jew was much more popular. Rex, the kingdom of Rexes ... (Ibid.)

Adam begins his clown routine. He makes his son-in-law laugh and then also the growing crowd of cemetery beggars who gather around them in a ring at the site of his daughter's grave. But then Adam drops to all fours to kiss the soil there where there is no tombstone, and sees the hostile looking faces of the beggars, who are making a racket shaking their tin boxes of charity.

The laughter of the beggars exposes gold teeth. And mouths that are toothless. Dark caverns. Stench and grotesquery. The beggars see that the two men are shocked, and laugh. And laugh. And laugh. Money! Money! Geld! Geld! (Ibid.)

Adam's son-in-law, scared, instructs Adam to run, insisting that they leave. Adam says he cannot, that his body refuses, and thinks to himself that "it is God's doing." Wanting to laugh he "recalls Rex. Rex was, Rex is, Rex will always be. You will come from dust and to dust you will always return. Good old dust. They both stink. The usual odor. Soon they will be smoke. Smoke has no color, just odor" (Ibid., p. 144). They then leave, Adam following Joseph, crawling on all fours after him. The beggars are no longer frightening but, rather, are frightened themselves, screaming in a panic after Joseph and Adam, who "like a boy and his dog," leave with the beggars calling after them "Demon! Bug! Monster!" (Ibid.). 
In this passage, Adam and Joseph are thus referenced simultaneously in terms of a demand for money and as animal, as monstrous ${ }^{7}$ Adam here reiterates a point he makes earlier when he references Jews in terms of soap. Soap was the denigrating term that had been used in Israel to refer to Holocaust survivors with reference to the Nazi manufacturing of soap out of the bones of the Jews they killed. "Men are soap," Adam reflected,

they hold people in their hands, clean innocent sterilized people. Oh, that sterilization. Those cultivated rules of the game. Oh the latent terror of the fact that today you can say $I$ scrubbed him good, meaning I finished him off. And any paleface who looks like a refugee is a piece of soap. And soap has no body or muscles. Soap is what they made out of us ... He was soap personified and saponified, ambling through the markets in order not to have to face Ruth. The former Ruth Stein who was turned into a pillar of soap but escaped and became a golden crucifix. That's fate. The sign of circumcision she can erase with a knife, but what about the soap? (Ibid., p. 133)

The question of Jewish difference here thus emerges in relation to the European gentile and in relation to the Jewish woman who is present only in the form of an unmarked grave or, elsewhere in the book, in terms of a sexed figure who veers between victim of violence and sexual animality, her presence marked by death or absence. This violence is itself positioned in relation to the tension and conflict between two figures of men-Jew and non-Jew-and between man and animal.

The category "Israeli Jew," and I would suggest, the postcolonial generally, raises a question about how to understand the difference of woman precisely because the postcolonial, or here specifically the Israeli Jew, brings together two different lineages through which a single figure is reproduced-Greek and Jew or European and non-European. The difference of reproduction here is thus signified through the difference of a people rather than as the sexual difference within a people. The reproduction of this figure thus places the two lineages within the postcolonial in relation to the figure of woman. I will go on to suggest that an analysis of the definition of sexual difference in these terms reveals that the definition of the human, within European humanism, relies on the production of the difference of a people being concealed by the definition of sexual difference as the difference of the reproduction of the human. Reason, self-possession, and sovereignty then define the human rather than a subject who is simultaneously guest and host, constituted through a difference that undoes any claim to full self-representation and thus a subject unable to be in self-possession or to be sovereign in the terms of European modernity.

To attend to the specificity of the GreekJew coupling is to trace the question of Jewish difference back to the narrative of asylum in terms of a relation to God and to return to European modernity by way of what was prior to it, in terms of not only the Jew but also its many polytheistic others. In other words, the internal exile of the Greekjew, or of the postcolonial, is constitutively and substantively different from the internal exile of the feminine and the figure of woman. By making explicit the question of reproduction of a subject produced in a relation between differently marked "men" (be they Jew and non-Jew or God and man), understanding Israel through a consideration of asylum makes explicit the need for rethinking the human itself.

\section{Conclusion: Israeli Jew, Asylum, and the Question of the Human}

Kaniuk's novel, like Israel itself, brings together the narrative of origin of the Jewish Abrahamic covenant with God, together with the narrative of modern nationalism and the sense of an abandonment

7 Geld is the word in German for money, but it also refers to a castrated male animal. Given the context of this scene then, the choice to use this word in the English translation gives additional emphasis to the way in which the passage challenges the distinction between man and animal and also invokes an emasculated man. The Hebrew word for money, kesef ("כס), and the Hebrew word for "yearning," kissufim (כיסופים), share the same root. I do not know if Kaniuk weighed in on the choice to use the word geld in the English, but it makes for an interesting translation. 
by God "in the most advanced factory of Europe." In the novel, the refuge promised by God is returned to through the creation of a mental asylum within, but also in excess of, the asylum of the state Israel. Israel shows how asylum is not the negation of diaspora or of nation-state modernity but, rather, confounds the terms of negation by revealing what is remaindered by the categories of diaspora and nation-state modernity. In other words, to think about Israel in terms of asylum is to understand the postcolonial anachronistically as the territorialization of Greeks and Jews in a single polity, as well as within a single subject. ${ }^{8}$

Israel is defined both in terms of a liberal democracy and in terms of a Jewish country and thus combines two interrelated logics into one figure by creating the category "Israeli Jew." By two inter-related logics, I refer to what Derrida has described in terms of a Greek logic based on a metaphysics of presence and a Jewish and Abrahamic logic based in a tradition of relation to the text. In the latter, the Jew is situated as a guest to its own existence, a guest to its language and its land through its relation to God via the text-who is both host and who demands of the Jews that they "host" him. This is the distinction that Derrida points out when he critiques Levinas for reinstituting a metaphysics of presence by placing a relation to alterity in terms of a dimension of height through a relation to the presence of God or the Divine. To do so, Derrida suggests, is to place difference in the plane of the ontological where it can be anticipated rather than opening the ontological to an other through which existence as presence cannot be fully present to itself. Such an opening is a form of hospitality that Derrida connects to the impossibility of forgiveness.

The scene in Kaniuk's novel in which Adam Stein moves between laughter and tears at his daughter's unmarked grave in Israel, returns us to Derrida's opening in his essay on "hostipitality." Derrida begins:

We have not yet encountered this strange possibility, regarding hospitality, the possibility of laughter ... We have often spoken of mourning, of hospitality as mourning, of burial, of Oedipus and Don Juan, and recently even about the work of mourning as a process of hospitality, and so on.

But we have not evoked laughter. Yet it is difficult to dissociate a culture of hospitality from a culture of laughter or a culture of smile... This is part of its essence in a way, even if the smile is interior and discreet, and even if it is mixed with tears ... (2002, p. 358)

Derrida goes on to ask what one should await from laughter, what one should expect of it. ${ }^{9}$ Saying that we know nothing of this, he goes on to remind us that we do know enough however to tell ourselves that

hospitality, what belabors and concerns hospitality at its core [ce qui travaille l'hospitalite en son sein], what works it like a labor, like a pregnancy, like a promise as much as like a threat ... is indeed a contradictory conception, a thwarted [contrariee] conception, or a contraception of awaiting, a contradiction of welcoming itself. And something that binds perhaps, as in Isaac's pregnancy [la grossesse d'Isaac], the laughter at pregnancy, at the announce of childbirth. Abraham, of whom we will speak a lot today, laughs, like Sarah, at the announce of Isaac's birth (Yishaq means 'he laughs'). (Ibid., pp. 359-60)

Derrida elaborates on this contradiction at the heart of hospitality, which he connects to forgiveness, because to welcome the other, to be open and hospitable to the other without knowing what he, she, or it is in advance, is also to forgive this other of "whatever his fault or his indignity, whatever the offense

8 This could also be understood then as a figure and a place of "hostipitality" (Derrida 2002, p. 358).

9 Derrida here references both Abraham's laughter and Sarah's laughter. While it might be argued that Sarah's laughter is cathartic or laughter filled with delight in response to the news that she will bear a child, her laughter has also been read as bitter, derisive, and skeptical. Why she laughs (and why she denies having laughed) is left open and uncertain, as others have noted (see Gift 2012; Henz-Piazza 2004). 
or even the threat," to forgive but also to ask for forgiveness for being structurally lacking and at fault for being unable, by definition, to ever give enough to or to expect enough the welcomed unexpected visitor or arriving one and thereby being positioned "so as to abandon the other, so as not to give him enough, and thus to leave him abandoned" (Ibid., p. 381). This brings Derrida to a notion of the messianic without messianism or messiah and to Jewishness through the impossibility of forgiveness.

Derrida recalls here the joke of two Jews, longtime enemies, who meet at a synagogue on Yom Kippur, the Jewish day of Atonement. One Jew says to the other, "I wish for you what you wish for me." The other one retorts, "Already you are starting again?" (Ibid.). There is no forgiveness without memory, but also forgiveness is not reducible to memory, Derrida writes. "A story for laughs," but what, Derrida goes on to ask, "makes us laugh, laugh or cry, and laugh through the tears or anguish?" (Ibid., p. 382). He goes on to point out that, in this moment of laughter between the two Jews who make the gesture of forgiving, who fake it, they persist with the conflict, making legible the impossibility of forgiveness, but also that, in enduring together this impossibility, a kind of compassion is possible, both in being unable to ask and in being unable to grant forgiveness. Returning to Israel, we can follow this question of hospitality and abandonment in terms of the Jewish narrative of a relation to God, exile, and the promise of refuge and thus also of selection by God.

In Kaniuk's novel, the asylum in the Negev is both a return to the place of refuge promised by God to his people and the result of his abandonment of his people, his failure to grant them refuge, hospitality. The refuge promised and failed by the nation-state is layered on top of the refuge promised and failed by God, and these two failures come together in the madness of the mental asylum and the struggle between the ideal of the rational human subject and the mad, unreasonable, Jewish survivor of the camps, not fully human. "The guilt of the survivor," Derrida writes,

... is not only that of the concentration camp survivor, but, first of all, of any survivor, of anyone who is mourning, of all the work of mourning-and the work of mourning is always an 'I survive,' and is therefore of the living in general-regarding the originary guilt of the living as survivor who must therefore be forgiven simply for the fact of living and of surviving the death of the other ... (Ibid., p. 383)

Derrida here calls attention to the displacement through which the self-deconstruction of hospitality is hidden through a logic of substitution there where no substitution is possible, where the subject is irreplaceable. It is here where Derrida demands an attention the presence of the third, of the other of the other that enters into the relation of the face to face, a specter without ontological or concrete predicates or what Derrida calls a silence at the heart of the call of the other. It is a silence, or an illegibility, that comes from the abyss of the relation between ethics and politics, ethics and law-a silence that demands a decision be taken without full knowledge. To be hospitable is "to let oneself be overtaken [surprendre], to be ready to not be ready, if such is possible, to let oneself be overtaken, to not even let oneself be overtaken, to be surprised, in a fashion almost violent ... " (Ibid., p. 361). This process of substitution and hospitality is also part of the archival logic of fraternity on which Western democratic traditions have been based.

Derrida, in drawing attention to the relation between hospitality and hostility in terms of an ethical relation to the other, raises the question of what it would mean for the figure of woman, and thus of sexual difference, to enter into this relation of substitution. It is worth quoting here at some length from Derrida's essay, "A Word of Welcome," written in memory of Levinas after his death. Derrida writes:

In the final pages of Totality and Infinity, we find the same themes of hospitable peace and uprooted wandering. Bypassing the political in the usual sense of the term, the same logic opens a wholly other space: before, beyond, outside the State. But one must wonder why it now centers this 'situation,' no longer on the femininity of welcoming, but on paternal fecundity, on what Levinas calls, and this would be another large question, yet another marvel, the 'marvel of the family.' This marvel concretizes 'the infinite time of fecundity' -a 
non-biological fecundity, of course - 'the instant of eroticism and the infinity of paternity.' (1999, p. 93)

Derrida remarks that here Levinas replaces the figure of woman as host with the paternal figure of the Divine as host. The figure of the third for Levinas then becomes signified in terms of the relation between oneself, another, and God, in which the figure of woman as ground is displaced by the figure of God as that which hosts and gives ground to man. For Levinas, this host and the election of the guest are tied to the narrative of the Old Testament.

Levinas presents a philosophy of ethics of relation to the other based on a relation to alterity. But Derrida points out that the manner in which Levinas bases his understanding of a relation to alterity in terms of a relation to the divine in the figure of God ultimately reinstitutes a metaphysics of being by placing the presence of God in the plane of being rather than placing being in a relation with the unknown other of alterity. In "A Word of Welcome," Derrida (1999) addresses this move in terms of the relation between Levinas's philosophy of an ethics of relation to the other and his political positions on Zionism and Israel and in terms of the question of sexual difference.

The presence of the third, of the other of the other that enters into the relation of the face to face, a specter without ontological or concrete predicates, presents what Derrida calls a silence at the heart of the call of the other. It is a silence, or an illegibility, that comes from the abyss of the relation between ethics and politics, ethics and law-a silence that demands that a decision be taken without full knowledge. Derrida writes that he hears such a silence in Lévinas' conclusion that speaks of a hope beyond refuge. Lévinas writes:

What is promised in Jerusalem ... is a humanity of the Torah. It will have been able to surmount the deep contradictions of the cities of refuge: a new humanity that is better than a Temple. Our text, which began with the cities of refuge, reminds us or teaches us that the longing for Zion, that Zionism, is not one more nationalism or particularism; nor is it a simple search for a place of refuge. It is the hope of a science of society, and of a society, which are wholly human. And this hope is to be found in Jerusalem, in the earthly Jerusalem, and not outside all places, in pious thoughts. (1994, p. 52)

Derrida suggests that there is a silence at the heart of this call, which highlights the exposure of the law to itself, as non-law, in the moment in which law becomes both host and hostage, "when the law of the unique must give itself over to substitution and to the law of generality ... when the "Thou shall not kill' ... still allows any State ... to feel justified in raising an army, in making war or keeping law and order, in controlling its borders-in killing" (Derrida 1999, p. 116). This openness, or silence, at the heart of the call and speech of the other, is what conditions and marks the beginning of responsibility; it marks the moment of indecision, the discontinuity between what Derrida calls "the messianic promise [unconditional hospitality] and the determination of a rule, norm, or political law" (Ibid., p. 117). He continues:

This discontinuity, moreover, allows us to subscribe to everything Levinas says about peace or messianic hospitality, about the beyond of the political in the political, without necessarily sharing all the 'opinions' in his discourse having to do with an intrapolitical analysis of real situations or of what is actually going on today with the earthly Jerusalem, or indeed with a Zionism that would no longer be just one more nationalism ... (Ibid. pp. 117-18)

To be responsible to Levinas, Derrida suggests, is to respond to this contradiction, to the places in the text that interrupt themselves. The "earthly reality" of contemporary Israel, by bringing together two different fraternal narratives, thus creates a situation in which these narratives encounter and contest one another. An analysis of the political claims made in the name of the category "Israeli Jew" might, as Khanna puts it in her work on psychoanalysis, allow us "to understand how the idea of being is attached in the modern period to both self-possession and material possession; as critics of 
international law remind us, belonging becomes linked to land through property" (Khanna 2014a, see also Khanna 2007).

Israel has been framed as a place intended to provide unconditional hospitality and welcome to all and any Jews, but also as a liberal democracy, with the values of citizenship, freedom, equality, and universal human rights that liberal democracy carries with it. It is defined, therefore, both as explicitly singular-as a Jewish state that was officially established in the aftermath of WWII-and as generalizable in its particularity as one of many liberal democracies. The figure of the Jew then also becomes generalizable, highlighting the contradictions of liberal democracy's inability to guarantee universal and unconditional hospitality, as Leo Strauss, and differently Hannah Arendt, famously pointed out. However, Israel also thereby reproduces those contradictions within the framework of a Jewish state, bringing into question the concept of the human in relation to which the Israeli Jew is defined.

Adam Resurrected ends with Adam narrating in a letter to his son-in-law Joseph that Herbert died and that he, Adam, survives as his living tombstone. The dog-child recovers and leaves the institute a young man. Adam is understood to have recovered, though he himself is uncertain, and he returns to live with the landlady Ruthie in Tel Aviv. Adam tells Joseph goodbye and good luck and ends with "may all dogs talk to one another" (Kaniuk [1969] 1971, p. 370). Khanna, in reference to the novel and a discussion of Israel, suggests that we think in planetary terms, highlighting that "the figure coming into the mental asylum or seeking political asylum becomes human though a process of becoming subject-forced into a recognizable form as if the inhuman state of being before those laws, and indeed after them, could be erased" (Khanna 2014b, p. 144).

It is through such erasure that the notion of the human is sustained and reinforced, through the violent elision of the difference internal to a people and the difference between a people. Women and men, marked as different in religious, ethnic, racialized, or national terms, both sustain and threaten the boundary between human and animal produced through this elision. Humanism's response to the threat such subjects pose is to base politics on terms of equivalence-citizen, human, community-in which difference is understood as the distinction between subjects rather than as the internal difference of the foreign that undoes claims to subjectivity from within. An analysis of the category "Israeli Jew" thus reveals the violence of discourses based on identity politics, belonging, and community, whether these discourses are under the sign of revolutionary struggle, suicide bombings, state terror, liberalism, or various forms of nationalism. Difference as that which is not fully inside the polity nor fully outside then becomes a threat. For Derrida, difference is the unknown, the foreign, before it has been identified as inside or outside, friend or enemy, human, animal, or divine. Difference is the circumcision through which subjectivity is simultaneously made possible and undone. An analysis of Israel in these terms can thus turn us back to the hope for the possibility of a democracy to come, based not on an Aristotelian political subject but on an openness to the foreign that undoes the human itself.

Funding: This research received no external funding.

Conflicts of Interest: The author declares no conflict of interest.

\section{References}

Abramson, Glenda. 2011. 'The first of those who return': Incarnations of the New Jew in modern Hebrew literature. The Journal of Israeli History 30: 45-63. [CrossRef]

Almog, Oz. 2000. The Sabra: The Creation of the New Jew. Berkeley: University of California Press.

Arnold, Mathew. 2009. Culture and Anarchy. Oxford: Oxford University Press. First published 1869.

Avner, Falk. 1996. A Psychoanalytic History of the Jews. Cransbury: Associated University Presses.

Bartal, Israel. 2010. The other story: Israeli historians and Jewish 'universalism'. European Review of History 17: 541-49. [CrossRef]

Bauer, Bruno. 2000. The Jewish Problem. San Diego: Contrarian Press. First published 1843. 
Boyarin, Jonathan. 1996. Palestine and Jewish History: Criticism at the Borders of Ethnography. Minneapolis: University of Minnesota Press.

Boyarin, Daniel. 1997. Unheroic Conduct: The Rise of Heterosexuality and the Invention of the Jewish Man. Berkeley: University of California Press.

Boyarin, Daniel, and Jonathan Boyarin, eds. 1997. Jews and Other Differences. Minneapolis: University of Minnesota Press.

Butler, Judith. 2012. Parting Ways: Jewishness and the Critique of Zionism. New York: Columbia University Press.

Chakrabarty, Dipesh. 2000. Provincializing Europe: Postcolonial Thought and Historical Difference. Princeton: Princeton University Press.

Conforti, Yitzhak. 2006. Alternative Voices in Zionist Historiography. Journal of Modern Jewish Studies 4: 1-12. [CrossRef]

Davison, Neil. 1998. James Joyce, Ulysses, and the Construction of Jewish Identity: Culture, Biography, and 'the Jew' in Modernist Europe. Cambridge: Cambridge University Press.

Derrida, Jacques. 1985. The Ear of the Other. Edited by Christie McDonald. Translated by Peggy Kamuf. Lincoln: University of Nebraska Press.

Derrida, Jacques. 1999. Adieu to Emmanuel Levinas. Stanford: Stanford University Press.

Derrida, Jacques. 2002. Acts of Religion. Edited by Gil Anidjar. New York: Routledge.

Engelberg, Ari. 2015. Modern Orthodoxy in Post-Secular Times: Jewish Identities on the Boundaries of Religious Zionism. Journal of Modern Jewish Studies 14: 126-39. [CrossRef]

Feiner, Shmuel. 2002. The Jewish Enlightenment. Philadelphia: University of Pennsylvania Press.

Gift, Kristine. 2012. Sarah's Laughter as Her Lasting Legacy: An Interpretation of Genesis 18:9-15. In MJUR. Monmouth: Monmouth Coe College Press, pp. 99-110.

Gilman, Sander L. 1991. The Jew's Body. New York: Routledge.

Gilman, Sander L. 1993a. Freud, Race, and Gender. Princeton: Princeton University Press.

Gilman, Sander L. 1993b. The Case of Sigmund Freud: Medicine and Identity at the Fin De Siècle. Baltimore: Johns Hopkins University Press.

Grosz, Elizabeth. 1995. Space, Time and Perversion: Essays on the Politics of Bodies. New York: Routledge.

Henz-Piazza, Gina. 2004. Why Did Sarah Laugh? In Distant Voices Drawing Near: Essays in Honor of Antoinette Clark Wire. Edited by Holly E. Hearon. Collegeville: Liturgical Press.

Herzl, Theodor. 2018. The Jewish State. An Attempt at a Modern Solution of the Jewish Question. Whithorn: Anodos Books, New York: American Zionist Emergency Council. First published 1896.

Herzl, Theodor. 2009. Old New Land. Princeton: M. Wiener Publishing. First published 1902.

Hess, Tamar. 2016. Self as Nation: Contemporary Hebrew Autobiography. Lebanon: Brandeis University Press.

Idelson-Shein, Iris. 2014. Difference of a Different Kind: Jewish Constructions of Race during the Long Eighteenth Century. Philadelphia: University of Pennsylvania Press.

Irigaray, Luce. 1987. Speculum of the Other Woman. Ithaca: Cornell Univ. Press.

Kalmar, Ivan Davidson, and Derek Jonathan Penslar. 2005. Orientalism and the Jews. Lebanon: Brandeis University Press.

Kaniuk, Yoram. 1971. Adam Resurrected. [Adam Ben Kelev]. Translated by Seymour Simckes. New York: Atheneum. First published 1969. (In Hebrew)

Khanna, Ranjana. 2003. Dark Continents. Durham: Duke Press.

Khanna, Ranjana. 2007. Indignity. Positions: East Asia Cultures Critique 16: 39-77. [CrossRef]

Khanna, Ranjana. 2014a. "Unbelonging" Lecture for the Humanities "theory" Panel for the "Sensational Humanities" Conference, Cornell University, Society Ithaca, NY, USA, November 20. Available online: https://vimeo.com/112419281 (accessed on 20 November 2014).

Khanna, Ranjana. 2014b. Rex, Or the Negation of Wandering. In Deconstructing Zionism. Edited by Gianni Vattimo and Michael Marder. New York: Bloomsbury Publishing, pp. 133-45.

Leonard, Miriam. 2012. Socrates and the Jews: Hellenism and Hebraism from Moses Mendelssohn to Sigmund Freud. Chicago: University of Chicago Press.

Lévinas, Emmanuel. 1994. Beyond the Verse: Talmudic Readings and Lectures. Bloomington: Indiana University Press.

Levy, Lital. 2014. Poetic Trespass: Writing Between Hebrew and Arabic in Israel/Palestine. Princeton: Princeton University Press.

Librett, Jeffrey S. 2014. Orientalism and the Figure of the Jew. New York: Fordham Press. 
Loewenberg, Peter, and Irving Stone. 1970. A Hidden Zionist Theme in Freud's My Son, the Myops—Dream. Journal of the History of Ideas 31: 129-32. [CrossRef] [PubMed]

Marx, Karl. 2012. On the Jewish Question. Chicago: Aristeus Books. First published 1844.

Mosse, George L. 1992. Max Nordau, Liberalism and the New Jew. Journal of Contemporary History 27: 565-81. [CrossRef]

Nancy, Jean-Luc. 2000. Being Singular Plural. Stanford: Stanford University Press. First published 1996.

Nelson, Cary, and Gabriel Noah Brahm. 2014. The Case Against Academic Boycotts of Israel. MLA Members for Scholar's Rights. Detroit: Wayne State University Press.

Nordau, Max. 1897. Nordau's Speech to the First Zionist Congress. Available online: http://www.mideastweb.org/ nordau1897.htm (accessed on 19 March 2015).

Palumbo-Liu, David. 2015. Breaking Taboos, BDS Gains Ground Among Academics. The Nation. Available online: http://www.thenation.com/article/194233/breaking-taboos-bds-gains-ground-among-academics (accessed on 15 June 2019).

Pappe, Ilan. 2014. The Idea of Israel: A History of Power and Knowledge. London: Verso Press.

Peled, Yoav. 1992. From theology to sociology: Bruno Bauer and Karl Marx on the question of Jewish emancipation. History of Political Thought 13: 463-85.

Pellegrini, Ann. 1997. Performance Anxieties: Staging Psychoanalysis, Staging Race. New York: Routledge.

Penslar, Derek Jonathan. 1991. Zionism and Technocracy: The Engineering of Jewish Settlement in Palestine, 1870-1918. Bloomington: Indiana University Press.

Rolnik, Eran. 2013. Freud in Zion. London: Karnac Books.

Shafir, Gershon, and Yoav Peled. 2002. Being Israeli: The Dynamics of Multiple Citizenship. Cambridge: Cambridge University Press.

Shaked, Gershon, and Yaron Peleg. 1996. Through Many Small Windows, by the Back Door: An Introduction to Postrealistic Hebrew Literature, 1950-80. Prooftexts 16: 271-91.

Shohat, Ella. 2017. On the Arab-Jew, Palestine, and Other Displacements: Selected Writings. London: Pluto Press.

Slavet, Eliza. 2009. Racial Fever: Freud and the Jewish Question. New York: Fordham University Press.

Smith, Charles D. 2007. Palestine and the Arab-Israeli Conflict. Boston: Bedford/St. Martin's Press.

Strauss, Leo. 1965. Spinoza's Critique of Religion. Chicago: University of Chicago Press.

van Vliet, Netta. 2016. Review of Deconstructing Zionism: A Critique of Political Metaphysics. Critical Inquiry 42: 412-14. [CrossRef]

Vattimo, Gianni, and Michael Marder, eds. 2014. Deconstructing Zionism: A Critique of Political Metaphysics. New York: Bloomsbury Press.

Yakobson, Alexander, and Amnon Rubinstein. 2010. Israel and the Family of Nations: The Jewish Nation-State and Human Rights. London: Routledge.

Yerushalmi, Yosef Hayim. 1993. Freud's Moses: Judaism Terminable and Interminable. New Haven: Yale University Press.

Yiftachel, Oren. 2006. Ethnocracy: Land and Identity Politics in Israel/Palestine. Philadelphia: University of Pennsylvania Press.

(C) 2020 by the author. Licensee MDPI, Basel, Switzerland. This article is an open access article distributed under the terms and conditions of the Creative Commons Attribution (CC BY) license (http://creativecommons.org/licenses/by/4.0/). 